\title{
SDF-1 Improves Renal Fibrosis in Type 2 Diabetes Mellitus Involving TGF- $\beta$-mediated ECM via PI3K/AKT Signalling
}

\begin{abstract}
J. XIE, JI ZHANG ${ }^{1}$ AND H. SHUAl ${ }^{2 *}$
Department of Endocrinology, Tongji Hospital, Affliated to Tongji Medical College, Huazhong University of Science \& Technology, Wuhan 430030, ${ }^{1}$ Department of Pharmacology, ${ }^{2}$ Department of Endocrinology, Xiangyang Central Hospital, Affiliated Hospital of Hubei University of Arts and Science, Xiangyang 441021, Hubei, China
\end{abstract}

Xie et al.: SDF-1 improves renal fibrosis in DN

\begin{abstract}
The present study investigated the role of stromal cell-derived factor- 1 in the progression of renal injury in type 2 diabetic nephropathy. The 8-week old male $\mathrm{db} / \mathrm{db}$ mice were used as the model of diabetic nephropathy and aged-matched male C57BL/6 mice constituted the control group. Fasting blood glucose, 24 hour urinary albumin and the creatinine clearance rate were measured. The expressions of stromal cell-derived factor-1, CXC chemokine receptor 4 and F4/80 were detected. Normal rat kidney epithelial cells were exposed to stromal cell-derived factor-1 $\alpha$, high glucose, tumour growth factor- $\beta 1$, valsartan and LY294002, respectively. The extracellular matrix expression was evaluated. It was found that creatinine clearance rate was significantly decreased in 28 -week $\mathrm{db} / \mathrm{db}$ mice compared to the age-matched $\mathrm{C57 \textrm {BL } / 6}$ mice and valsartan could significantly increase creatinine clearance rate. The expression of stromal cell-derived factor-1, CXC chemokine receptor 4 and F4/80 was significantly increased in the kidney of $\mathrm{db} / \mathrm{db}$ mice but not in $\mathrm{C57BL} / 6$ mice, which was improved with valsartan treatment. In vitro, the expression of CXC chemokine receptor 4 was detected in the rat kidney epithelial cells. Tumour growth factor- $\beta 1$ increased the expressions of type IV collagen and fibronectin in rat kidney epithelial cells under low glucose and high glucose condition. Stromal cell-derived factor-1 $\alpha$ inhibited the harmful effect of tumour growth factor- $\beta 1$ on extracellular matrix expression, and valsartan exerted synergistic effect on stromal cell-derived factor-1 $\alpha$. Stromal cell-derived factor-1 $\alpha$ decreased tumour growth factor- $\beta 1$ expression and increased p-AKT expression, which were inhibited by LY294002 treatment. Stromal cell-derived factor-1 improved renal fibrosis which might partly involve TGF- $\beta$-mediated extracellular matrix via PI3K/AKT pathway.
\end{abstract}

Key words: Diabetic nephropathy, stromal cell derived factor-1, tumour growth factor- $\beta$, PI3K-AKT pathway

Type 2 diabetes mellitus (T2DM) often resulted in microvascular and macrovascular complications, including nephropathy, atherosclerosis, neuropathy and retinopathy. There is increasing evidence that low-level chronic inflammation may in part contribute to the pathogenesis of T2DM and its associated complications ${ }^{[1,2]}$. Crook et al..$^{[3]}$ proposed that T2DM is an inflammatory state. They found that acute-phase protein levels such as serum sialic acid and IL-6 were elevated in T2DM patients, suggesting that inflammation might be related to the development of $\mathrm{T}^{2} \mathrm{DM}^{[3,4]}$. It is well established that inflammatory markers such as TNF- $\alpha$, IL-6 and C-reactive protein are associated with $\mathrm{T} 2 \mathrm{DM}$ and increased risk of $\mathrm{T} 2 \mathrm{DM}^{[5,6]}$. Studies have

*Address for correspondence E-mail: cnhongxiashuai@163.com

January-February 2020 shown that proinflammatory molecules such as TNF- $\alpha$ and IL- 6 cause insulin resistance through activating JNK and IKK $\beta$ pathways ${ }^{[7]}$.

There is increasing evidence that low-level chronic inflammation contribute to the pathogenesis of diabetic nephropathy $(\mathrm{DN})^{[8]}$. Evidence has shown that macrophages and $\mathrm{T}$ cells accumulate in the kidney of $\mathrm{T}_{2} \mathrm{DM}^{[9]}$. These activated macrophages and leukocytes

This is an open access article distributed under the terms of the Creative Commons Attribution-NonCommercial-ShareAlike 3.0 License, which allows others to remix, tweak, and build upon the work non-commercially, as long as the author is credited and the new creations are licensed under the identical terms

Accepted 21 November 2019 Revised 29 August 2019 Received 17 June 2019 Indian J Pharm Sci 2020;82(1):66-75 
produce various reactive oxygen species, cytokines and proteases. Proinflammatory molecules involved in the progression of DN include chemokines, inflammatory cytokines and adhesion molecules. Renal chronic inflammation is associated with not only promoting glomerular sclerosis and interstitial fibrosis but elevating albuminuria and plasma creatinine ${ }^{[10]}$.

Stromal cell-derived factor-1 (SDF-1), a CXC subfamily chemokine, is a pre-B-cell growth factor ${ }^{[1]}$. Studies demonstrated that SDF-1 and its receptor, CXCR4, are involved in embryogenesis, migration, progenitor cell homing, survival, proliferation, differentiation and fibrosis ${ }^{[12,13]}$. Reports showed that SDF-1 binding to the specific receptor CXCR4 participates in the immune and inflammation reaction ${ }^{[14]}$. Angiotensin II receptor blockers has been shown to reduce the progression of $\mathrm{DN}^{[15]}$. In the present study, the expression of SDF-1/ CXCR4 was investigated in the kidney of type 2 diabetic $\mathrm{db} / \mathrm{db}$ mice and the role of SDF-1 and valsartan on extracellular matrix (ECM) accumulation in normal rat kidney epithelial (NRK) cells. Additionally, it was hypothesized that SDF-1/CXCR4 improved renal fibrosis through transforming growth factor- $\beta$ TGF- $\beta$ PI3K/AKT pathway.

\section{MATERIALS AND METHODS}

Male $\mathrm{db} / \mathrm{db} \quad\left(\right.$ Lepr $\left.^{\mathrm{db} / \mathrm{db}}\right)$ and male C57BL/6 mice (8-w old) were purchased from Shanghai Experimental Animal Centre (Shanghai, China). NRK cell line was purchased from cell centre of Xiangya School of Medicine (Changsha, China). Valsartan was procured from Novartis Pharmaceuticals Company Limited (Beijing, China). AntiCXCR4 antibody for immunohistochemistry was from Abcam. AntiSDF-1 antibody for immunohistochemistry was from BioVision. AntiF4/80 antibody for immunohistochemistry was from Abd-Serotec. SDF-1 $\alpha$ and TGF- $\beta 1$ were purchased from PeproTech. AntiAKT antibody and antipAKT antibody (Ser 473) for western blot were from Santa Cruz. Antitype IV collagen antibody and antifibronectin antibody for western blot were from Shanghai Bio-platform Technology Company (Shanghai, China). Anti $\beta$-actin antibody was from GeneTex.

\section{Animal grouping and treatments:}

Ten male $\mathrm{db} / \mathrm{db}$ mice ( 8 -w old) were used as type 2 diabetic model and ten male C57BL/6 mice (8-w old) served as age-matched control. Valsartan $(40 \mathrm{mg} /$ $\mathrm{kg} / \mathrm{d}$ ) was administrated orally by gavage once a day at
3:00 pm. The groups were divided as followed control (C57BL/6 mice); C57BL/6 mice+valsartan; db/db mice; $\mathrm{db} / \mathrm{db}$ mice+valsartan. The mice were housed in a room maintained at $24 \pm 2^{\circ}$ and a $12 \mathrm{~h} \mathrm{light/dark}$ cycle. Mice were allowed free access to mouse chow and sterile water throughout the experimental periods. Body weight and fasting blood glucose (FBG) levels were monitored weekly, while at the beginning and ending of the experiment, fasting blood and $24 \mathrm{~h}$ urine were collected. Blood and urine were centrifugated for $5 \mathrm{~min}(1200 \mathrm{rpm})$ and were stored at $-80^{\circ}$. Twenty weeks later, the mice were sacrificed under light ether anaesthesia, both kidneys were excised from each mouse and embedded in a cryostat to prepare frozen sections. Protein was extracted and stored at $-80^{\circ}$. This study was carried out in strict accordance with the recommendations in the Guide for the Care and Use of Laboratory Animals of the National Institutes of Health. The animal use protocol has been reviewed and approved by the Institutional Animal Care and Use Committee (IACUC) of Hubei University of Arts and Science.

\section{Estimation of creatinine and urinary albumin in mice:}

FBG was measured using blood glucose teat strips (Onetouch Surestep, Qiangsheng, USA). Creatinine was measured by the alkaline trinitrophenol method. Urinary albumin was evaluated by radioimmunoassay. Creatinine clearance rate $(\mathrm{CCr})$ was calculated as $\mathrm{CCr}=(\mathrm{UCr} \times$ urine volum $) /(\mathrm{SCr} \times$ body weight $)$, where, $\mathrm{UCr}$ represents urine creatinine and $\mathrm{SCr}$ represents serum creatinine.

\section{Cell culture and treatment conditions:}

NRK cells were cultured in DMEM ( $25 \mathrm{mM}$ glucose) media containing $100 \mathrm{U} / \mathrm{ml}$ penicillin and $100 \mu \mathrm{g} / \mathrm{ml}$ streptomycin supplemented with $10 \%$ foetal calf serum at $37^{\circ}$, under humidified atmosphere of $5 \% \mathrm{CO}_{2}$ in air. To evaluate the effect of TGF- $\beta$ on the expression of CXCR4, cells were divided into 2 groups, high glucose medium $(25 \mathrm{mM})$, high glucose medium $(25 \mathrm{mM})+$ TGF- $\beta 1\left(3 \times 10^{-10} \mathrm{M}\right)$. Cells were cultured for $3,6,12$ and $24 \mathrm{~h}$ and collected. To evaluate the effect of SDF-1 on the expression of type IV collagen and fibronectin (FN), cells were divided into 10 groups, low glucose medium $(5.6 \mathrm{mM})$, low glucose medium (5.6 mM)+DMSO, low glucose medium $(5.6 \mathrm{mM})+$ TGF- $\beta 1\left(3 \times 10^{-10} \mathrm{M}\right)$, low glucose medium $(5.6 \mathrm{mM})+$ TGF $-\beta 1\left(3 \times 10^{-10} \mathrm{M}\right)+$ SDF- $1 \alpha\left(3 \times 10^{-9} \mathrm{M}\right)$, low glucosemedium $(5.6 \mathrm{mM})+\mathrm{TGF}-\beta 1\left(3 \times 10^{-10} \mathrm{M}\right)+\mathrm{SDF}-1 \alpha$ 
$\left(3 \times 10^{-9} \mathrm{M}\right)+$ valsartan $\left(10^{-5} \mathrm{M}\right)$, high glucose medium (25 mM), high glucose medium (25 mM)+DMSO, high glucose medium $(25 \mathrm{mM})+$ TGF- $\beta 1\left(3 \times 10^{-10} \mathrm{M}\right)$, high glucose medium $(25 \mathrm{mM})+$ TGF- $\beta 1\left(3 \times 10^{-10} \mathrm{M}\right)+\mathrm{SDF}-$ $1 \alpha\left(3 \times 10^{-9} \mathrm{M}\right)$, high glucose medium $(25 \mathrm{mM})+$ TGF- $\beta 1$ $\left(3 \times 10^{-10} \mathrm{M}\right)+$ SDF-1 $\alpha \quad\left(3 \times 10^{-9} \mathrm{M}\right)+$ valsartan $\left(10^{-5} \mathrm{M}\right)$. Cells were pre-treated with TGF- $\beta 1$ for $3 \mathrm{~h}$. Cells were cultured for $24 \mathrm{~h}$ and were collected.

To evaluate the signalling pathway of SDF-1 on renal fibrosis, cells were divided into 10 groups, low glucose medium $(5.6 \mathrm{mM})$; low glucose medium $(5.6 \mathrm{mM})+\mathrm{SDF}-1 \alpha\left(3 \times 10^{-9} \mathrm{M}\right)$; low glucose medium $(5.6 \mathrm{mM})+$ SDF-1 $\alpha\left(3 \times 10^{-9} \mathrm{M}\right)+\mathrm{LY} 294002(30 \mu \mathrm{M})$; low glucose medium $(5.6 \mathrm{mM})+\mathrm{LY} 294002(30 \mu \mathrm{M})$; high glucose medium $(25 \mathrm{mM})$; high glucose medium $(25 \mathrm{mM})+\mathrm{SDF}-1 \alpha\left(3 \times 10^{-9} \mathrm{M}\right)$; high glucose medium $(25 \mathrm{mM})+$ SDF-1 $\alpha\left(3 \times 10^{-9} \mathrm{M}\right)+\mathrm{LY} 294002(30 \mu \mathrm{M})$. Cells were pre-treated with LY294002 for $30 \mathrm{~min}$. Cells were cultured for $24 \mathrm{~h}$ and were collected.

\section{Immunohistochemistry staining of CXR4, SDF-1 and $\mathbf{F 4 / 8 0}$ in the kidney of mice:}

Freshly isolated kidney specimens were embedded and frozen in the frozen embedding agent and sectioned at $5 \mu \mathrm{m}$. The slides were deparaffinized in dimethyl benzene and digested in trypsin. After permeabilized with $0.025 \%$ Triton-X 100 for $10 \mathrm{~min}$ at room temperature (RT), the slides were incubated with $3 \% \mathrm{H}_{2} \mathrm{O}_{2}$ for 10 min at RT. Primary antibodies to macrophage marker F4/80 (1:200), SDF-1 (1:200), or CXCR4 (1:200) were incubated overnight at $4^{\circ}$. Phosphate buffered saline (PBS) was used as the negative control to replace the primary antibodies. After rewarmed to RT for $45 \mathrm{~min}$, the slides were incubated with the appropriate secondary antibodies at RT for $20 \mathrm{~min}$. The sections were incubated with avidin-biotin-peroxidase complex at RT for $20 \mathrm{~min}$. After washed with PBS, the sections were stained with DAB. After stained with hematoxylin again, the slides were dehydrated and mounted, observed and photographed under optical microscope. Pro Plus 6.0 image analysis system was used to analyse the expression, and randomly three visual fields were selected under 400 times light microscope per section to calculate average optical.

\section{Western blot of ECM and AKT pathway in NRK cell:}

Total protein was extracted from cells and concentrations were measured using BCA protein assay kit. Equal amounts of protein were separated by $10 \%$ SDS-PAGE and transferred onto nitrocellulose membranes. Then the membranes were blocked for $1 \mathrm{~h}$ with $5 \%$ nonfat dry milk and were incubated with specific primary antibodies of AKT (1:200), p-AKT (1:200), type IV collagen (1:200), Fn (1:200) and $\beta$-actin $(1: 250)$ overnight at $4^{\circ}$. Horseradish peroxidase-conjugated secondary antibodies (1:1000) were incubated for $1 \mathrm{~h}$ at RT. The protein bands were visualized and quantified by enhanced chemiluminescence using an imaging software.

\section{Real-time PCR of CXCR4 and SDF-1 expression in mouse kidney and ECM expression in NRK cell:}

Total RNA was extracted using Trizol reagent according to the manufacturer's recommended protocol. The RNA concentration was determined by measuring $\mathrm{UV}$ absorbance at $260 \mathrm{~nm}$. Isolated RNA was reverse transcribed into cDNA. Synthesized cDNA was then amplified by real-time PCR using SYBR green master mix. Real-time PCR was performed using TagMan gene expression assays, with $\beta$-act in and GAPDH as internal standards. All PCR were performed in a total volume of $20 \mu \mathrm{l}$. Quantitative real-time PCR for $=$ SDF- $1 \alpha$, CXCR 4 , TGF- $\beta 1$, FN1 and type IV collagen was performed at $94^{\circ}$ for 2 min followed by 45 cycles of denaturing at $94^{\circ}$ for $30 \mathrm{~s}$, annealing at $56^{\circ}$ for $30 \mathrm{~s}$ and extension at $72^{\circ}$ for $30 \mathrm{~s}$. Quantitative real-time PCR for rat type IV collagen and rat GAPDH was performed at $94^{\circ}$ for 2 min followed by 45 cycles of denaturing at $94^{\circ}$ for $30 \mathrm{~s}$, annealing at $57^{\circ}$ for $30 \mathrm{~s}$ and extension at $72^{\circ}$ for $30 \mathrm{~s}$. The PCR primer sequences were shown in Table 1.

\section{Agarose gel electrophoresis for CXCR4 expression in NRK cell:}

Total RNA was extracted from four group NRK cells using TRIzol reagent, respectively. Isolated RNA was reverse transcribed into cDNA. Synthesized cDNA was then amplified by PCR. PCR was performed at $94^{\circ}$ for $5 \mathrm{~min}$ followed by 35 cycles of denaturing at $94^{\circ}$ for $30 \mathrm{~s}$, annealing at $55^{\circ}$ for $30 \mathrm{~s}$ and extending at $72^{\circ}$ for $30 \mathrm{~s}$. After agarose gel electrophoresis $(1.5 \%)$, the sample were stained with ethidium bromide and photographed under ultraviolet lamp. The PCR primer sequence of CXCR4, forward primer TAGTGGGCAATGGGTTGGTAATC and reverse primer CTGCTGTAAAGGTTGACGGTGTA. The markers of DNA molecular weight is DL-2000.

\section{Statistical analyses:}

Data were presented as mean \pm SD. Statistical analyses 
were performed using SPSS Software 13.0 (SPSS, Inc., Chicago, IL, USA). The significance of the differences among the results of clinical characteristic was valued by T-test. ANOVA was used to determine the significance of the differences among the results of western blot, real-time PCR and immunohistochemistry of the groups.

\section{RESULTS AND DISCUSSION}

The body weight, FBG and $24 \mathrm{~h}$ urinary albumin in $8-\mathrm{w}$ and $28-\mathrm{w}$ old $\mathrm{db} / \mathrm{db}$ mice were higher compared with those in the same age C57BL/6 mice, respectively $(\mathrm{p}<0.01)$. In $28-\mathrm{w}$ old $\mathrm{db} / \mathrm{db}$ mice, the body weight, FBG and $24 \mathrm{~h}$ urinary albumin were high than those in 8 -w old $\mathrm{db} / \mathrm{db}$ mice $(\mathrm{p}<0.01)$. In contrast, $28-\mathrm{w}$ old $\mathrm{db} / \mathrm{db}$ mice had lower $\mathrm{CCr}$ compared to that in agematched C57BL/6 mice $(\mathrm{p}<0.01)$. Valsartan treatment could significantly decrease body weight, 24 h urinary albumin and increased $\mathrm{CCr}$, but had no significant influence on FPG in $\mathrm{db} / \mathrm{db}$ mice. The effect of valsartan was not found in C57BL/6 mice (Table 2).

Immunohistochemical staining for SDF-1, CXCR4 and $\mathrm{F} 4 / 80$ in the kidney specimens obtained from $\mathrm{C} 57 \mathrm{BL} / 6$ mice and $\mathrm{db} / \mathrm{db}$ mice were performed. In renal glomerulus, tubule and interstitium, sections from $\mathrm{db} / \mathrm{db}$ mice showed intensive positive granulometric staining for SDF-1, CXCR4 and F4/80 than those in
C57BL/6 mice. Valsartan treatment could attenuate the deposition in $\mathrm{db} / \mathrm{db}$ mice. The effect of valsartan was also not found in C57BL/6 mice (fig. 1 and Table 3).

The mRNA levels of SDF-1 and CXCR4 were evaluated in the kidney of mice (fig. 2). The mRNA levels of SDF-1 and CXCR4 in $\mathrm{db} / \mathrm{db}$ mice were significantly higher than those in C57BL/6 mice $(\mathrm{p}<0.01)$. Valsartan treatment significantly decreased the mRNA level of SDF-1 in $\mathrm{db} / \mathrm{db}$ mice $(\mathrm{p}<0.01)$. Valsartan decreased the expression of CXCR4 mRNA but the difference was not significant. Valsartan treatment had no effect of mRNA levels of SDF-1 and CXCR4 in C57BL/6 mice (fig. 2).

CXCR4 expression in NRK cells was measured by immunohistochemistry and agarose gel electrophoresis. Using immunohistochemistry it was found that the positive granulometric staining for CXCR4 in renal tubule of C57BL/6 mice and db/db mice (figs. 3A, B). Agarose gel electrophoresis showed that CXCR4 mRNA was expressed in renal tubular epithelial cell (fig. 3). Furthermore, TGF- $\beta 1$ could promote CXCR4 mRNA expression in 3, 6, 12 and $24 \mathrm{~h}$ and the peak time was 3 h (fig. 3).

The effect of SDF-1 on ECM (type IV collagen and FN) mRNA and protein expression was explored with different concentrations of glucose in the medium in

\section{TABLE 1: PRIMERS FOR GENES}

\begin{tabular}{lcc}
\hline Genes & \multicolumn{1}{c}{ Forward } & Reverse \\
\hline Mouse SDF-1a & CATCGCCAGAGCCAACGTCAAG & GTCCTTTGGGCTGTTGTGCTTAC \\
Mouse CXCR4 & ACGGCTGTAGAGCGAGTGTTG & GGGTTCCTTGTTGGAGTCATAG \\
Rat SDF-1a & GCCAGAGCCAACGTCAAACATC & GGATCCACTTTAATTTCGGGTCAA \\
Rat type IV collagen & GCAGTGGCAAAGCGAGAATACC & AGTTACACGCCGAGCGAGGAGA \\
Rat FN & GGACACTATGCGGGTCACTTGG & TGCTGTTCGTACACGCTGGAGA \\
Rat TGF-B1 & GCTGAACCAAGGAGACGGAATA & CACCTCGACGTTTGGGACTGA \\
MouseB-actin & TGCTGTCCCTGTATGCCTCTG & CTTTGATGTCACGCACGATTTC \\
Rat GAPDH & GATGGTGAAGGTCGGTGTG & GAGGTCAATGAAGGGGTCG \\
\hline
\end{tabular}

TABLE 2: COMPARISON OF CLINICAL CHARACTERISTICS AMONG DIFFERENT GROUPS

\begin{tabular}{lccccc}
\hline Group & Age $(\mathrm{w})$ & Body weight $(\mathrm{g})$ & FBG $(\mathrm{mM})$ & $24 \mathrm{~h}$ urinary albumin $(\mu \mathrm{g} / 24 \mathrm{~h})$ & $\mathrm{CCr}(\mathrm{ml} \times \mathrm{min} \times \mathrm{kg})$ \\
\hline C57BL/6 & 8 & $20.99 \pm 1.58$ & $4.36 \pm 0.38$ & $23.76 \pm 1.46$ & $0.32 \pm 0.06$ \\
& 28 & $27.5 \pm 2.56$ & $5.48 \pm 1.10$ & $25.03 \pm 0.85$ & $0.36 \pm 0.16$ \\
C57BL/6+valsartan & 8 & $19.38 \pm 2.13$ & $5.12 \pm 1.74$ & $22.68 . \pm 2.27$ & $0.37 \pm 0.07$ \\
& 28 & $25.3 \pm 1.76$ & $5.74 \pm 0.73$ & $24.86 \pm 1.09$ & $0.38 \pm 0.07$ \\
$\mathrm{db} / \mathrm{db}$ & 8 & $36.76 \pm 2.98^{*}$ & $7.98 \pm 1.29^{*}$ & $170.43 \pm 9.83^{*}$ & $1.71 \pm 0.44^{*}$ \\
& 28 & $51.33 \pm 1.73^{*}$ & $23.87 \pm 3.46^{*}$ & $259.52 \pm 11.24^{*}$ & $1.11 \pm 0.09^{*}$ \\
$\mathrm{db} / \mathrm{db}+$ valsartan & 8 & $37.65 \pm 1.81^{*}$ & $8.76 \pm 0.56^{*}$ & $175.07 \pm 11.34^{*}$ & $1.49 \pm 0.24^{*}$ \\
& 28 & $47.4 \pm 2.79^{*}$ & $22.84 \pm 3.29^{*}$ & $206.00 \pm 14.40^{*}$ & $1.42 \pm 0.12^{*} \Delta$ \\
\hline
\end{tabular}

Comparison of clinical characteristics among groups. The body weight, FBG and $24 \mathrm{~h}$ urinary albumin were higher and $\mathrm{CCr}$ was lower in $\mathrm{db} /$ $\mathrm{db}$ mice than those in age matched C57BL/ 6 mice respectively. Valsartan treatment could significantly decrease body weight, $24 \mathrm{~h}$ urinary albumin and increased CCr. " $\mathrm{P}<0.01$ versus the age matched C57BL/6 group and C57BL/6+valsartan group respectively; ${ }^{\triangle} \mathrm{p}<0.01$ versus the $8 \mathrm{w}$ old $\mathrm{db} / \mathrm{db}$ group 


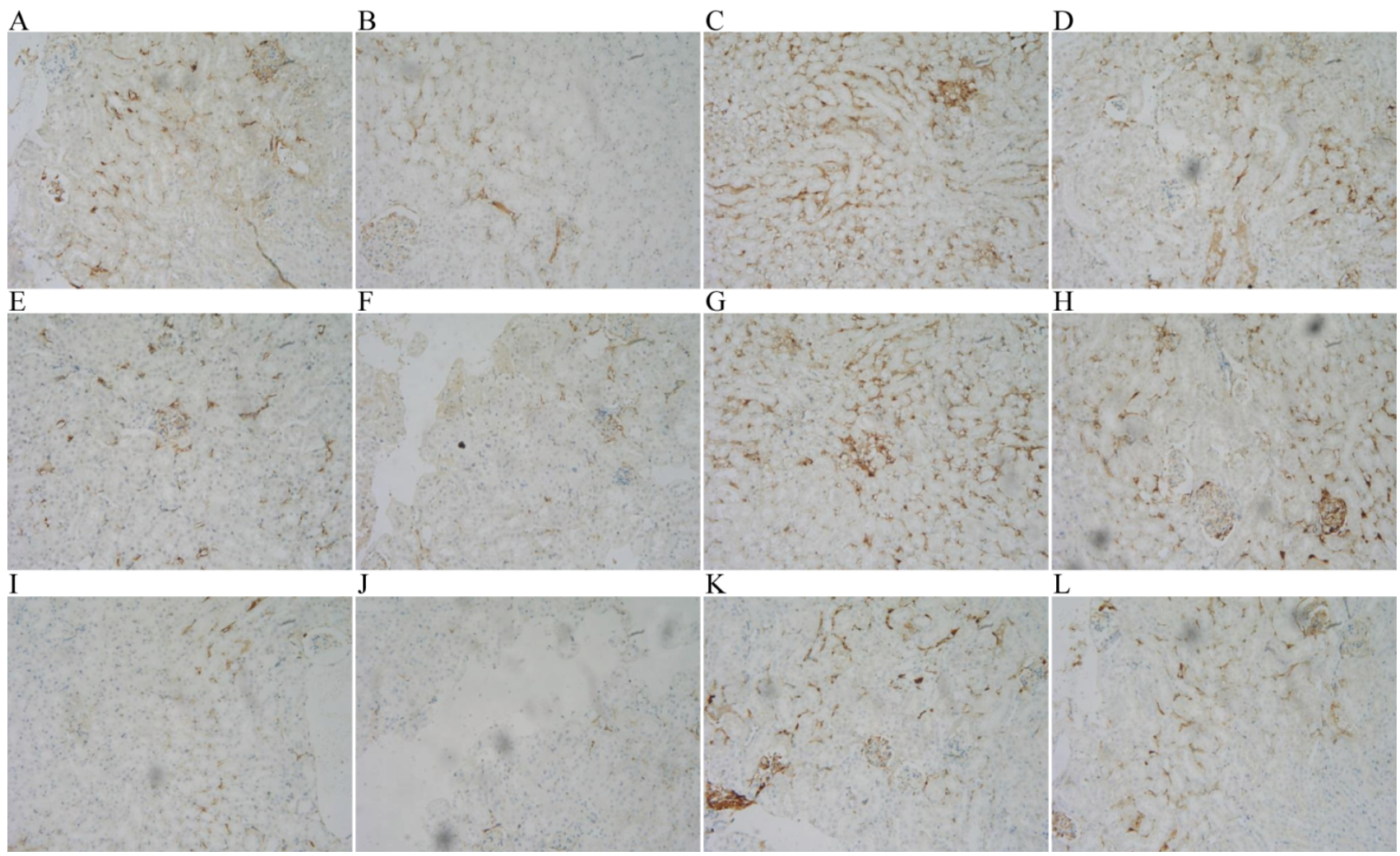

Fig. 1: SDF-1, CXCR4 and F4/80 deposits in the kidney of mice

SDF-1, CXCR4 and F4/80 deposits were evaluated by immunohistochemistry. A-D SDF-1 deposits in A. C57BL/6 mice; B. C57BL/6 mice+valsartan, C. db/db mice, D. db/db mice+valsartan. E-H CXCR4 deposits in E. C57BL/6 mice F. C57BL/6 mice+valsartan, G. db/db mice, H. db/db mice+valsartan. I-L F4/80 deposits in I. C57BL/6 mice, J. C57BL/6 mice+valsartan, K. db/db mice, L. db/ db mice+valsartan. In db/db mice, SDF-1, CXCR4 and F4/80 deposits were more strongly than those in C57BL/6 mice. Valsartan treatment attenuated SDF-1 deposition in $\mathrm{db} / \mathrm{db}$ mice

TABLE 3: QUANTIFICATION OF IHC STAIN (AVERAGE OPTICAL) IN EACH GROUP

\begin{tabular}{lccc}
\hline Group & SDF-1 & CXCR4 & F4/80 \\
\hline C57BL/6 & $0.151 \pm 0.021$ & $0.163 \pm 0.032$ & $0.139 \pm 0.030$ \\
C57BL/6+Valsartan & $0.147 \pm 0.023$ & $0.137 \pm 0.029$ & $0.149 \pm 0.025$ \\
db/db & $0.623 \pm 0.049^{*}$ & $0.463 \pm 0.057^{*}$ & $0.573 \pm 0.062^{*}$ \\
db/db+Valsartan & $0.353 \pm 0.059^{* *}$ & $0.288 \pm 0.056^{* *}$ & $0.337 \pm 0.053^{* *}$ \\
\hline
\end{tabular}

Immunohistochemistry staining of CXR4, SDF-1 and F4/80 in the kidney of mice was calculated by average optical (AO). The deposition of SDF-1, CXCR4 and F4/80 was elevated in $\mathrm{db} / \mathrm{db}$ mice than that in C57BL/6 nice and was attenuated by valsartan treatment. ${ }^{*} \mathrm{P}<0.01$ versus the age matched C57BL/ 6 group and C57BL/6+valsartan group respectively; ${ }^{* *} \mathrm{p}<0.01$ versus the $8 \mathrm{w}$ old $\mathrm{db} / \mathrm{db}$ group

NRK cells. Surprisingly, treated with SDF- $1 \alpha\left(3 \times 10^{-9} \mathrm{M}\right)$ in low $(5.6 \mathrm{mM})$ and high glucose $(25 \mathrm{mM})$ medium, the mRNA and protein levels of type IV collagen and Fn were significantly down-regulated $(\mathrm{p}<0.01$, fig. 4). High glucose $(25 \mathrm{mM})$ significantly induced type IV collagen and FN mRNA and protein expression ( $<<0.01$, fig. 5). Compared to the control, TGF- $\beta$ significantly increased the mRNA and protein expression of type IV collage and FN. When the cells were treated with SDF-1 $\alpha$, the increased effect of TGF- $\beta 1$ on the levels of type IV collagen and FN mRNA was inhibited $(p<0.01)$. Valsartan had synergistic effect on SDF-1 $\alpha$ in this effect ( $<<0.01$, fig. 5).

To explore the mechanism of SDF-1 suppressing the ECM expression in NRK, the expression of TGF- $\beta 1$ treated with SDF-1 $\alpha$ was measured. Compared to the control group in low and high glucose medium, SDF- $1 \alpha$ treatment significantly down-regulated TGF- $\beta 1$ mRNA expression $(p<0.01$, fig. $6 \mathrm{~A})$. NRK cells were treated with LY294002 to explore the role of PI3K/AKT pathway in the effects of SDF-1 suppressing TGF- $\beta 1$ expression. Real-time PCR showed that LY294002 inhibited the suppression of TGF- $\beta 1$ expression by SDF-1 $\alpha \quad(p<0.01$, fig. 6A). Western blot analysis showed that SDF-1 $\alpha$ significantly increased AKT activity and LY294002 inhibited the effect of SDF-1 $\alpha$ on AKT activity (figs. 6B, C). LY29400 had no effect on AKT activity in the absence of SDF- $1 \alpha$.

Abundant evidence has demonstrated that chemokines such as monocyte chemoattractant protein-1 (MCP-1) 

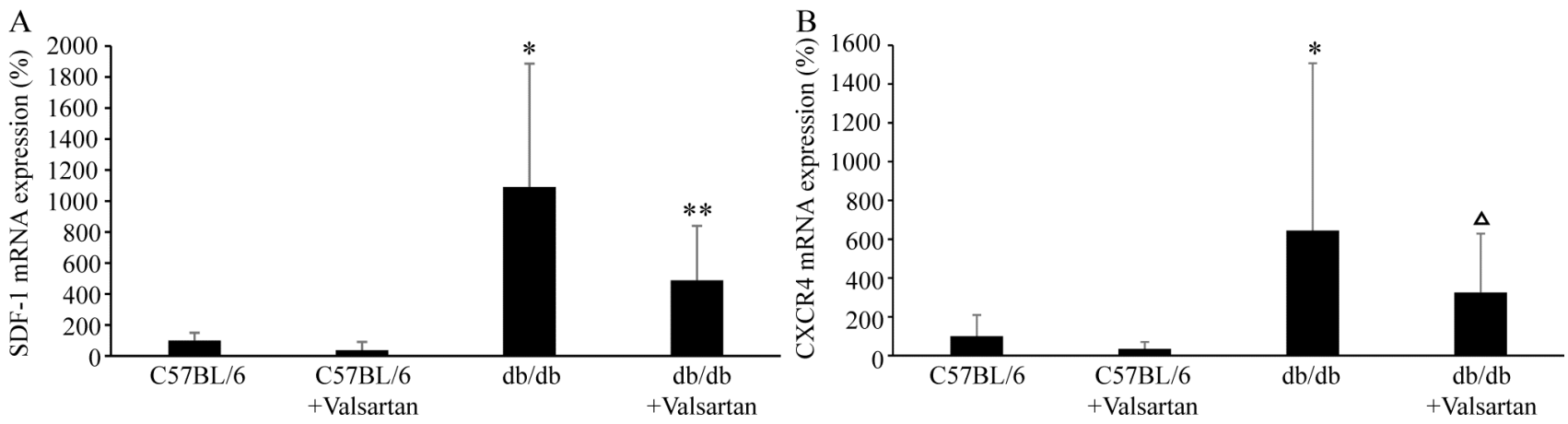

Fig. 2: mRNA expression levels of SDF-1 and CXCR4 in the kidney of mice

The expression of SDF-1 and CXCR4 in $\mathrm{db} / \mathrm{db}$ mice was significantly higher than those in C57BL/6 mice and valsartan treatment significantly decreased the expression of SDF-1 in db/db mice. Valsartan decreased the expression of CXCR4 mRNA but the difference was not significant. ${ }^{*} \mathrm{P}<0.01$ versus $\mathrm{C} 57 \mathrm{BL} / 6$ and $\mathrm{C} 57 \mathrm{BL} / 6+$ valsartan respectively; ${ }^{* *} \mathrm{p}<0.01 \mathrm{vs}$. $\mathrm{db} / \mathrm{db} ;{ }^{\Delta} \mathrm{p}>0.05 \mathrm{versus}$ $\mathbf{d b} / \mathbf{d b}$

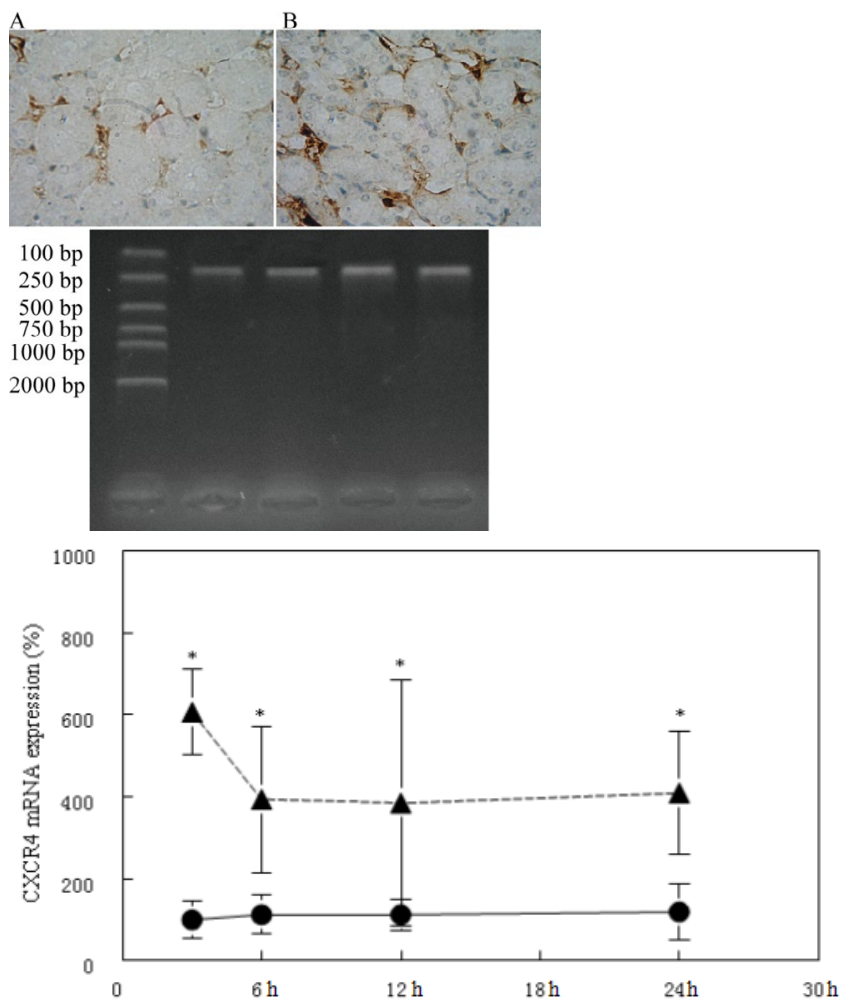

Fig. 3: CXCR4 deposits in renal tubule of mice and NRK cells A. C57BL/6 mice $\mathrm{B}$. $\mathrm{db} / \mathrm{db}$ mice. The brown product present in the renal tubule using immunohistochemistry. CXCR4 mRNA expressed in NRK cells (four groups) by agarose gel electrophoresis. The product length of PCR was $211 \mathrm{bp}$. (-॰-) control; (- $\triangle-$ ) TGF- $\beta$ promoted the expression of CXCR4 mRNA in NRK cells and the peak time was 3 h. ${ }^{\text {* }} \mathbf{P}<0.01$ versus control

are associated with $\mathrm{T} 2 \mathrm{DM}^{[16]}$. Obesity induces macrophage accumulation in adipose tissue and produces many proinflammatory cytokines and chemokines ${ }^{[17]}$. These cytokines and chemokines could reduce insulin sensitivity via inhibiting insulin receptor signaling and activating intracellular pathways including IKK $\beta, \mathrm{NF}-\mathrm{\kappa B}$ and JNKs to induce insulin resistance ${ }^{[18,19]}$. Moreover, inflammatory molecules may participate in the pathogenesis of diabetic complication, including $\mathrm{DN}^{[20]}$. Accumulating evidences indicates that chemokines play an important role in renal inflammation and are involved in processes related to $\mathrm{DN}^{[21]}$. Glomerular and interstitial macrophage infiltration has been demonstrated in $\mathrm{DN}^{[22]}$. SDF-1 is a CXC chemokine and its receptor is CXCR4, a seven transmembrane domain G-protein coupled receptor ${ }^{[23]}$. In our study, the expression of SDF-1 and CXCR4 was explored in the kidney of T2DM and the role of SDF-1 on the renal fibrosis. We used $\mathrm{db} / \mathrm{db}$ mice as a model of T2DM because $\mathrm{db} / \mathrm{db}$ mice develop to kidney disease two months after birth with similarities to human $\mathrm{DN}^{[24]}$. Compared with age-matched C57BL/6 mice, $28 \mathrm{w}$ age $\mathrm{db} / \mathrm{db}$ mice presented increased body weight, FPG and $24 \mathrm{~h}$ urinary albumin and decreased CCr. We detected SDF-1 and its receptor CXCR4 exists in the kidney of $\mathrm{db} / \mathrm{db}$ mice. $28 \mathrm{w} \mathrm{db} / \mathrm{db}$ mice had intensive depositions of SDF-1, CXCR4 and F4/80 (macrophage/ monocyte marker) in renal glomerulus, tubule, interstitial, which was associated with a significantly increase in renal inflammatory levels. Present study showed that valsartan could decrease the expression of SDF-1, CXCR4 and F4/80 infiltration and ameliorate the renal function. The effect of SDF-1 was further investigated on ECM expression in NRK with different concentration glucose medium.

In present study, immunohistochemistry and agarose gel showed that CXCR4 was exist in renal tubular epithelial cell, suggesting that SDF-1 could produce a marked effect through CXCR4 in renal tubular epithelial cell. Furthermore, TGF- $\beta 1$ could promote CXCR4 mRNA expression in NRK cells. Surprisingly, present study found that SDF-1 suppressed the mRNA and protein levels of type IV collagen and Fn in NRKs both in low $(5.6 \mathrm{mM})$ and high $(25 \mathrm{mM})$ glucose 

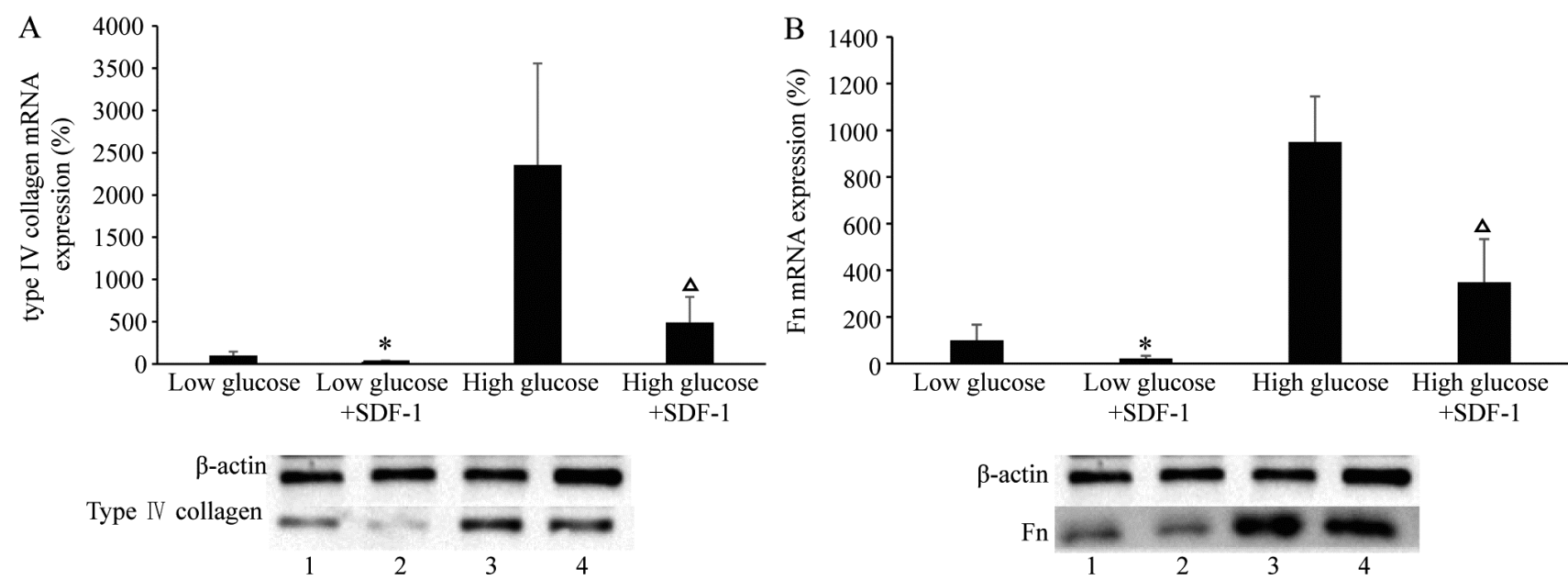

Fig. 4: Effect of SDF-1 on ECM expression in low and high glucose medium in NRK cells

1. Low glucose 2. low glucose+SDF-1, 3. high glucose, 4. high glucose+SDF-1. SDF-1 significantly down-regulated the mRNA and protein levels of type IV collagen and FN, respectively. ${ }^{*} \mathbf{P}<0.01$ versus low glucose; ${ }^{\triangleleft} \mathbf{p}<0.01$ versus high glucose
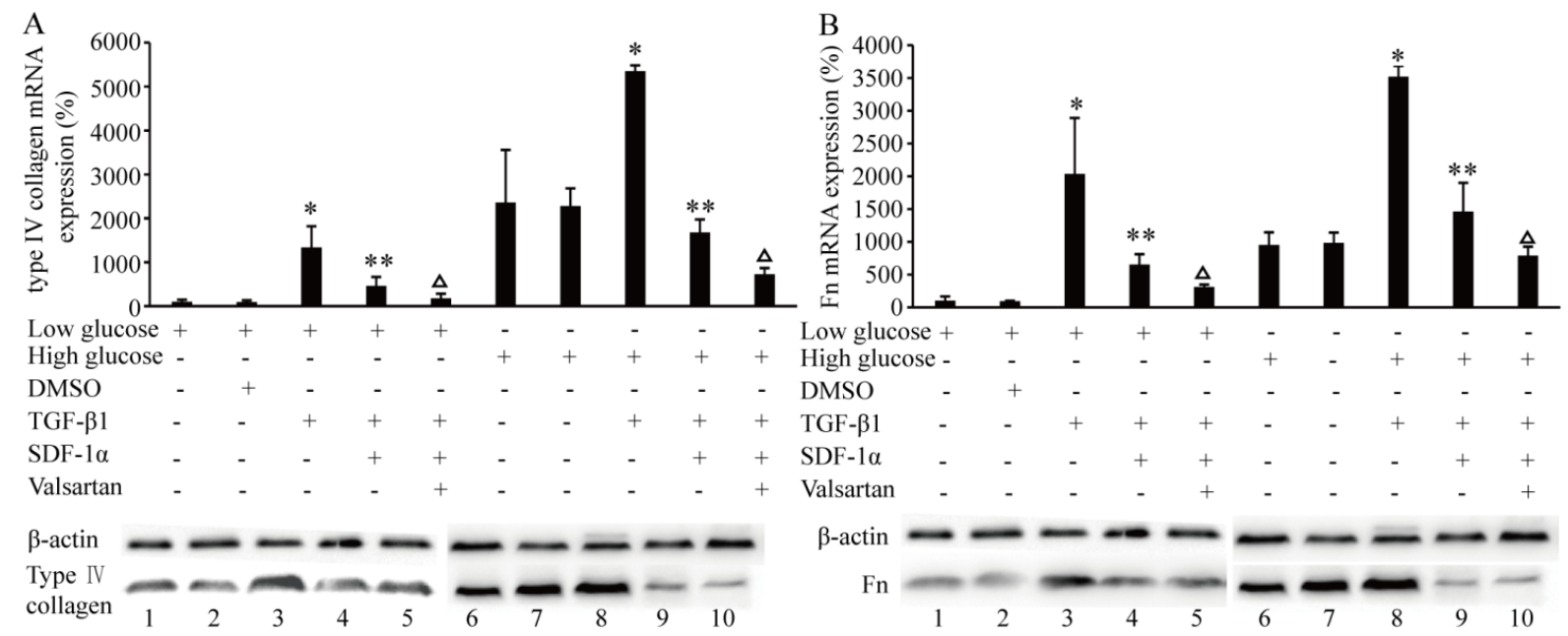

Fig. 5: Effect of SDF-1 on TGF- $\beta$-induced ECM expression in low and high glucose medium in NRK cells

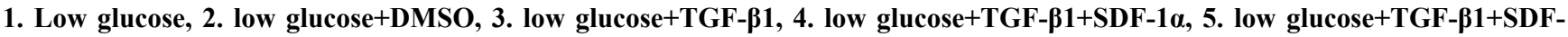
$1 \alpha+$ valsartan, 6. high glucose, 7. high glucose+DMSO, 8. high glucose+TGF- $\beta 1$, 9. high glucose+TGF- $\beta 1+$ SDF-1 $\alpha$, 10. high glucose+TGF- $\beta 1+$ SDF-1 $\alpha+v a l s a r t a n$. Compared control, TGF- $\beta$ significantly increased the mRNA and protein expression of type IV collage and FN. SDF-1 inhibited the TGF- $\beta$-induced mRNA expression in ECM. Valsartan had a synergistic effect of SDF-1. $* \mathbf{P}<0.01$ versus low and high glucose, respectively; $* * p<0.01$ versus low glucose+TGF- $\beta 1$ and high glucose+TGF- $\beta 1$ respectively; ${ }^{\Delta} \mathbf{p}<0.01$ versus low glucose+TGF- $\beta 1+$ SDF-1 $\alpha$ and high glucose+TGF- $\beta 1+$ SDF-1 $\alpha$

condition, suggesting the beneficial effect of SDF-1 on renal fibrosis in DN. In addition, it was found that SDF-1 significantly improved TGF- $\beta$ induced ECM deposition in NRKs. Valsartan orally administered for $20 \mathrm{w}$ in diabetic mice had synergistic effect on SDF-1 in the above effect. Therefore, our observations suggest that SDF-1 could retard the fibrosis progression of DN. This result contrasts to the reports that chemokines promoting renal fibrosis in $\mathrm{DN}^{[25]}$. $\mathrm{DN}$ is characterized by glomerulosclerosis and tubulointerstitial expansion followed by renal fibrosis ${ }^{[26]}$. Accumulation of ECM protein including collagens, FNs and laminins in the glomerular mesangium and tubulointerstitial results in renal fibrosis ${ }^{[27]}$. Chemokines such as MCP-1, interleukin-8 (CXCL8) and RANTES (CCL5) have been demonstrated to promote the development and progression of $\mathrm{DN}^{[25,28]}$. MCP-1 is a specific chemokine that can induce numerous macrophages to infiltrate the glomeruli and renal interstitium. Many studies demonstrated that MCP-1 promoted ECM accumulation to accelerate glomerula sclerosis and tubule interstitial fibrosis ${ }^{[29-31]}$. Studies revealed that cytokine gene polymorphisms may affect the progression of $\mathrm{DN}$. Gene polymorphism study revealed the risk association between A-2518G polymorphism in the regulatory region of $\mathrm{MCP}-1$ with $\mathrm{DN}^{[32]}$. Studies showed the positive correlation of CCR5 59029G/A with $\mathrm{DN}^{[33]}$. Although some studies have shown that SDF-1/ 


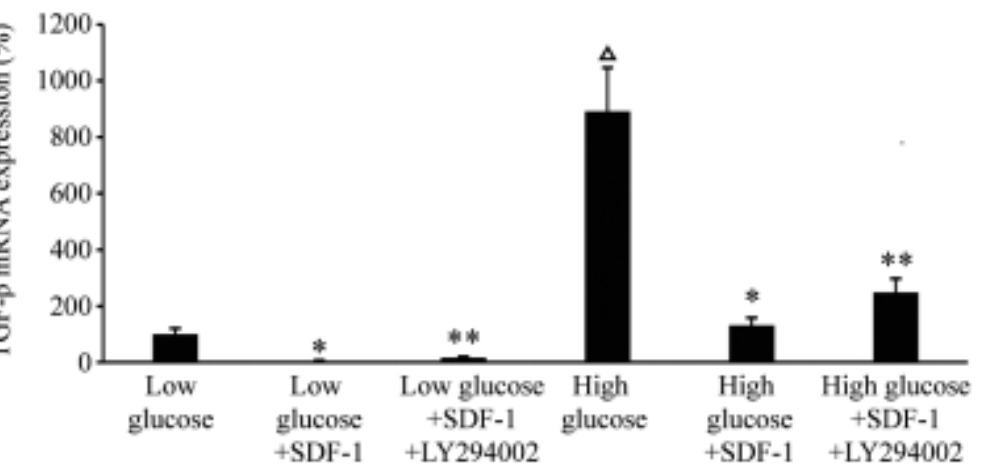

B

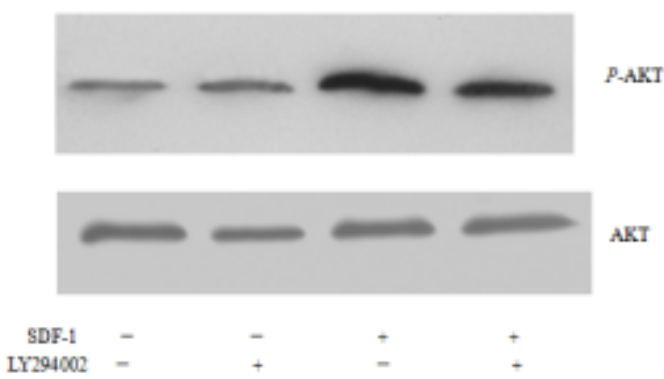

$\mathrm{C}$

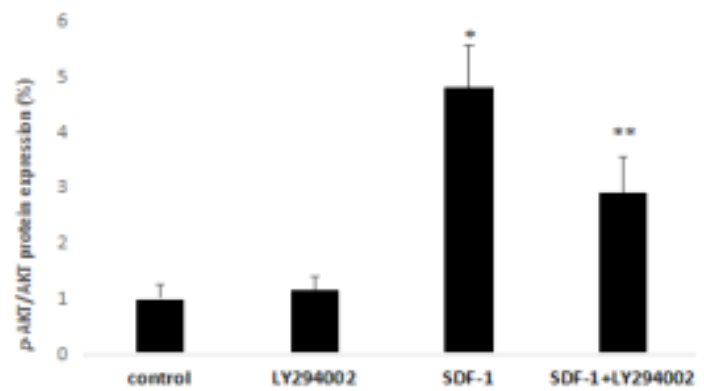

Fig. 6: The mechanism of SDF-1-induced suppression of ECM expression in NRK cells

AKT and phospho-AKT protein activities were evaluated by B. western blot and C. densitometric analysis. Phospho-AKT band intensity was normalized to AKT band intensity and was expressed as relative band intensity. Compared to control, SDF-1 treatment decreased TGF- $\beta$ mRNA expression. LY294002 treatment inhibited the effect of SDF-1 suppressing TGF- $\beta$ expression A. SDF-1 significantly increased AKT activity and this effect was inhibited by $L Y 294002$. ${ }^{*} \mathbf{P}<0.01$ versus control group; $* * 00.01$ versus SDF-1 group

CXCR4 axis promoted lung fibrosis ${ }^{[34]}$. SDF-1/CXCR4 signalling was able to promote ECM production in osteoclast $^{[35]}$. But some studies have shown that SDF1 could promote ECM degradation to promote tumour migration and invasion ${ }^{[36]}$. In present study, SDF-1 was found to reduce ECM generation, showing the ability to retard renal fibrosis. Meanwhile, it was also observed that the effect of valsartan on the renal fibrosis. In present study, valsartan orally administered for $20 \mathrm{w}$ decreased $24 \mathrm{~h}$ urinary albumin and increased $\mathrm{CCr}$ but had no significant influence on FPG. It was also observed that valsartan attenuated the infiltration of macrophage, SDF-1 and CXCR4 into the kidney and decreased type IV collagen and Fn accumulation. Present study suggested the beneficial effects of valsartan on renal damage in DN. These results were coincident with the previous studies ${ }^{[37]}$.

The mechanism underlying protective effect of SDF1 was further determined on renal fibrosis. TGF- $\beta$ has been known to promote ECM generation, glomerula sclerosis and tubule interstitial fibrosis ${ }^{[38]}$. The regulation between TGF- $\beta$ and other inflammatory mediates is exist. MCP-1 could promote renal fibrosis through inducing TGF- $\beta$ production ${ }^{[39]}$. In mesangial cells, TGF- $\beta$ promotes the progression of renal disease through stimulating MCP-1 production ${ }^{[40]}$. TGF- $\beta$ promotes renal fibrosis through some key signaling pathway, such as Smad2/3, PI3K/AKT, ERK1/2 pathway ${ }^{[41-43]}$. In present study, it was found that SDF1 inhibited TGF- $\beta$ production in NRKs and LY294002 inhibited the effect of SDF- $1 \alpha$ suppressing TGF- $\beta 1$ expression. Also SDF-1 $\alpha$ significantly increased AKT activity and LY294002 treatment inhibited SDF-1 increasing AKT activity. Our results showed that the mechanism of SDF-1 attenuating renal fibrosis might partly involve TGF- $\beta$-mediated ECM via PI3K/AKT signalling pathway. SDF-1/CXCR4 might become a new therapeutic strategy for DN.

\section{Acknowledgements:}

This study was supported by Xiangyang Science and Technology Projects ([2012] NO.40) and the National Natural Science Foundation of China (Grant No.81600643).

\section{Conflict of interest:}

None. 


\section{REFERENCES}

1. Meshkani R, Vakili S. Tissue resident macrophages: Key players in the pathogenesis of type 2 diabetes and its complications. Clin Chim Acta 2016;462:77-89.

2. Donath MY, Shoelson SE. Type 2 diabetes as an inflammatory disease. Nat Rev Immunol 2011;11:98-107.

3. Crook MA, Tutt P, Pickup JC. Elevated serum sialic acid concentration in NIDDM and its relationship to blood pressure and retinopathy. Diabetes Care 1993;16:57-60.

4. Greenfield JR, Campbell LV. Relationship between inflammation, insulin resistance and type 2 diabetes: 'cause or effect'? Curr Diabetes Rev 2006;2:195-211.

5. Fernández-Real JM, Pickup JC. Innate immunity, insulin resistance and type 2 diabetes. Diabetologia 2012;55:273-8.

6. Liu C, Feng X, Li Q, Wang Y, Li Q, Hua M. Adiponectin, TNF- $\alpha$ and inflammatory cytokines and risk of type 2 diabetes: A systematic review and meta-analysis. Cytokine 2016;86:1009.

7. Bastard JP, Maachi M, Lagathu C, Kim MJ, Caron M, Vidal $\mathrm{H}$, et al. Recent advances in the relationship between obesity, inflammation, and insulin resistance. Eur Cytokine Netw 2006; 17:4-12.

8. Barutta F, Bruno G, Grimaldi S, Gruden G. Inflammation in diabetic nephropathy: moving toward clinical biomarkers and targets for treatment. Endocrine 2015;48:730-42.

9. Tesch GH. Diabetic nephropathy - is this an immune disorder? Clin Sci 2017;131:2183-99.

10. Ruster C, Wolf G. The role of chemokines and chemokine receptors in diabetic nephropathy. Front Biosci 2008;13:94455.

11. Psenak O. Stromal cell-derived factor-1 (SDF-1). Its structure and function. Cas Lek Cesk 2001;140:355-63.

12. Wang Y, Luther K. Genetically manipulated progenitor/stem cells restore function to the infarcted heart via the SDF1alpha/CXCR4 signaling pathway. Prog Mol Biol Transl Sci 2012;111:265-84.

13. Hattori K, Heissig B, Tashiro K, Honjo T, Tateno M, Shieh $\mathrm{JH}$, et al. Plasma elevation of stromal cell-derived factor-1 induces mobilization of mature and immature hematopoietic progenitor and stem cells. Blood 2001;97:3354-60.

14. He G, Ma M, Yang W, Wang H, Zhang Y, Gao MQ. SDF-1 in Mammary Fibroblasts of Bovine with Mastitis Induces EMT and Inflammatory Response of Epithelial Cells. Int J Biol Sci 2017;13:604-14.

15. Ruilope LM, Segura J. Losartan and other angiotensin II antagonists for nephropathy in type 2 diabetes mellitus: a review of the clinical trial evidence. Clin Ther 2003;25:304464.

16. Panee J. Monocyte Chemoattractant Protein 1 (MCP-1) in obesity and diabetes. Cytokine 2012;60:1-12.

17. Harford KA, Reynolds CM, McGillicuddy FC, Roche HM. Fats, inflammation and insulin resistance: insights to the role of macrophage and T-cell accumulation in adipose tissue. Proc Nutr Soc 2011;70:408-17.

18. Lee BC, Lee J. Cellular and molecular players in adipose tissue inflammation in the development of obesity-induced insulin resistance. Biochim Biophys Acta 2014;1842:446-62.

19. Mancini SJ, White AD, Bijland S, Rutherford C, Graham $\mathrm{D}$, Richter EA, et al. Activation of AMP-activated protein kinase rapidly suppresses multiple proinflammatory pathways in adipocytes including IL-1 receptor-associated kinase-4 phosphorylation. Mol Cell Endocrinol 2017;440:44-56.
20. Navarro JF, Mora C. Role of inflammation in diabetic complications. Nephrol Dial Transplant 2005;20:2601-4.

21. Navarro-González JF, Mora-Fernández C, Muros de Fuentes M, García-Pérez J. Inflammatory molecules and pathways in the pathogenesis of diabetic nephropathy. Nat Rev Nephrol 2011;7:327-40.

22. Ahmed M, de Winther MPJ, Van den Bossche J. Epigenetic mechanisms of macrophage activation in type 2 diabetes. Immunobiology 2017;222:937-43.

23. Gupta SK, Lysko PG, Pillarisetti K, Ohlstein E, Stadel JM. Chemokine receptors in human endothelial cells. Functional expression of CXCR4 and its transcriptional regulation by inflammatory cytokines. J Biol Chem 1998;273:4282-7.

24. Breyer MD, Böttinger E, Brosius FC 3rd, Coffman TM, Harris $\mathrm{RC}$, Heilig CW, et al. Mouse models of diabetic nephropathy. J Am Soc Nephrol 2005; 16:27-45.

25. Pichler R, Afkarian M, Dieter BP, Tuttle KR. Immunity and inflammation in diabetic kidney disease: translating mechanisms to biomarkers and treatment targets. Am J Physiol Renal Physiol 2017;312:F716-31.

26. Pourghasem M, Shafi H, Babazadeh Z. Histological changes of kidney in diabetic nephropathy. Caspian J Intern Med 2015;6:120-7.

27. Alicic RZ, Rooney MT, Tuttle KR. Diabetic Kidney Disease: Challenges, Progress, and Possibilities. Clin J Am Soc Nephrol 2017;12:2032-45.

28. Boels MGS, Koudijs A, Avramut MC, Sol WMPJ, Wang G, van Oeveren-Rietdijk AM, et al. Systemic Monocyte Chemotactic Protein-1 Inhibition Modifies Renal Macrophages and Restores Glomerular Endothelial Glycocalyx and Barrier Function in Diabetic Nephropathy. Am J Pathol 2017;187:2430-40.

29. Chow FY, Nikolic-Paterson DJ, Ozols E, Atkins RC, Rollin BJ, Tesch GH. Monocyte chemoattractant protein-1 promotes the development of diabetic renal injury in streptozotocintreated mice. Kidney Int 2006;69:73-80.

30. Kanwar YS. TRB3: an oxidant stress-induced pseudokinase with a potential to negatively modulate MCP-1 cytokine in diabetic nephropathy. Am J Physiol Renal Physiol 2010;299:F963-4.

31. Tesch GH. MCP-1/CCL2: a new diagnostic marker and therapeutic target for progressive renal injury in diabetic nephropathy. Am J Physiol Renal Physiol 2008;294:F697-701.

32. Mao S, Huang S. Monocyte chemoattractant protein-1 -2518G/A gene polymorphism and the risk of nephropathy in type 2 diabetes mellitus among Asians: a meta-analysis. Ren Fail 2014;36:139-44.

33. Buraczynska M, Zukowski P, Wacinski P, Berger-Smyka B, Dragan M, Mozul S. Chemotactic cytokine receptor 5 gene polymorphism: relevance to microvascular complications in type 2 diabetes. Cytokine 2012;58:213-7.

34. Makino H, Aono Y, Azuma M, Kishi M, Yokota Y, Kinoshita $\mathrm{K}$, et al. Antifibrotic effects of CXCR4 antagonist in bleomycin-induced pulmonary fibrosis in mice. J Med Invest 2013;60:127-37.

35. Dong Y, Liu H, Zhang X, Xu F, Qin L, Cheng P, et al. Inhibition of SDF-1 $\alpha /$ CXCR4 Signalling in Subchondral Bone Attenuates Post-Traumatic Osteoarthritis. Int J Mol Sci 2016;17:E943.

36. Singh S, Singh UP, Grizzle WE, Lillard JW, Jr. CXCL12CXCR4 interactions modulate prostate cancer cell migration, metalloproteinase expression and invasion. Lab Invest 2004;84:1666-76.

37. Pathak JV, Dass EE. A retrospective study of the effects of 
angiotensin receptor blockers and angiotensin converting enzyme inhibitors in diabetic nephropathy. Indian J Pharmacol 2015;47:148-52.

38. Sutariya B, Jhonsa D, Saraf MN. TGF- $\beta$ : the connecting link between nephropathy and fibrosis. Immunopharmacol Immunotoxicol 2016;38:39-49.

39. Giunti S, Tesch GH, Pinach S, Burt DJ, Cooper ME, CavalloPerin $\mathrm{P}$, et al. Monocyte chemoattractant protein-1 has prosclerotic effects both in a mouse model of experimental diabetes and in vitro in human mesangial cells. Diabetologia 2008;51:198-207.

40. Cheng J, Diaz Encarnacion MM, Warner GM, Gray CE, Nath KA, Grande JP. TGF-betal stimulates monocyte chemoattractant protein-1 expression inmesangial cells through a phosphodiesterase isoenzyme 4-dependent process. Am J Physiol Cell Physiol 2005;289:C959-70.

41. Meng XM, Nikolic-Paterson DJ, Lan HY. TGF- $\beta$ : the master regulator of fibrosis. Nat Rev Nephrol 2016;12:325-38.

42. Li F, Li L, Hao J, Liu S, Duan H. Src Homology 2 DomainContaining Inositol 5'-Phosphatase Ameliorates High Glucose-Induced Extracellular Matrix Deposition via the Phosphatidylinositol 3-Kinase/Protein Kinase B Pathway in Renal Tubular Epithelial Cells. J Cell Biochem 2017;118:227184.

43. Suzuki H, Uchida K, Nitta K, Nihei H. Role of mitogenactivated protein kinase in the regulation of transforming growth factor-beta-induced fibronectin accumulation in cultured renal interstitial fibroblasts. Clin Exp Nephrol 2004;8:188-95. 